\title{
Castration of the stallion: Preferably in the standing horse by laparoscopic techniques?
}

\author{
Astrid B. M. Rijkenhuizen und G. C. M. Grinwis* \\ Faculty of Veterinary Medicine, Equine Sciences, Utrecht University \\ * Dept. of Pathology
}

\begin{abstract}
Summary
Progress in the laparoscopic techniques has made it possible to remove an abdominal testicle in the standing horse. As abdominal cryptorchidism is usually unilateral, the descended testicle is removed using a classic standing castration technique. However, this latter technique is not considered ideal as it is difficult to guarantee asepsis, and can be dangerous for the surgeon. Therefore, a study was initiated to castrate descended testicles in the standing horse using a laparoscopic technique. In six Welsh pony stallions, 2 years of age, each with 2 descended testicles, the mesorchium, including the testicular artery and vein, are ligated intraabdominally and the testicles are left in place. The measurements of plasmatestosteron levels, the clinical examination and the results of the necropsy of the ponies 5 months postoperatively revealed, that the testicles atrophy and were no longer functional. Also, the results of the surgery on 9 unilateral inguinal cryptorchids, one bilateral inguinal cryptorchid, 17 unilateral abdominal cryptorchids (of which 5 were castrated unilaterally), 2 bilateral abdominal cryptorchids and 12 „,normal " stallions are described.

In conclusion, the surgical technique described in this report is a safe and efficient method of castrating descended testicles in the standing patient. Advantages include reduced tissue trauma, no risk because of general anaesthesia, a quicker return to normal work and reduced hospitalization time.
\end{abstract}

Keywords: $\quad$ horse, equine, laparoscopy, castration

\begin{abstract}
Kastration des Hengstes in laparoskopischer Technik am stehenden Pferd
Der Fortschritt der laparoskopischen Techniken beim Pferd hat es ermöglicht, abdominale Hoden am stehenden Tier zu entfernen. Da der abdominale Kryptorchismus üblicherweise einseitig auftritt, wird der zweite, abgestiegene Hoden meist durch die klassische Methode am stehenden Pferd entfernt. Diese Technik kann jedoch nicht als ideal bezeichnet werden, weil ein aseptisches Vorgehen kaum möglich und der Eingriff für den Chirurgen nicht ungefährlich ist. Aus diesem Grunde wurde im Rahmen einer ersten Studie versucht, den abgestiegenen Hoden ebenfails durch laparoskpische Technik zu kastrieren. Bei 6 zweijährigen Welsh-Pony-Hengsten mit jeweils 2 abgestiegenen Hoden wurde das Mesorchium samt Arterie und Vene intraabdominal ligiert und die Hoden im Skrotum belassen. Messungen der Plasma-Testosteronspiegel, klinische Untersuchung und die Ergebnisse der pathologischen Untersuchung ergaben, dass die Hoden atrophieren und nicht länger funktionstüchtig bleiben. Im Rahmen dieser Arbeit werden die Ergebnisse der auf diese Weise durchgeführten Kastrationen von 9 einseitig inguinalen Kryptorchiden, einem beidseitig inguinalen Kryptorchiden, 17 einseitig abdominalen Kryptorchiden, von denen 5 einseitig vorkastriert waren, 2 beidseitig abdominalen Kryptorchiden und 12 „normalen“ Hengsten beschrieben. Zusammenfassend wird festgestellt, das die beschriebene Methode eine sichere und wirksame Technik zur Kastration des stehenden Hengstes darstellt. Die Vorteile liegen in reduziertem Gewebstrauma, keiner Inkaufnahme eines Narkoserisikos, kürzerer Rekonvalseszenz und kürzerem Klinikaufenthalt.
\end{abstract}

Schlüsselwörter: Pferd, Laparoskopie, Kastration

\section{Introduction}

Progress in the laparoscopic techniques has made it possible to remove an abdominal testicle in the standing horse. Various authors describe how the testicle is grasped and exteriorized through the abdominal wall; the ligation and transection of the abdominal testicle occur extracorporally (Fischer and Vachon 1992, Davis 1997). As abdominal cryptorchidism is usually unilateral, the descended testicle is removed using a classic standing castration technique. However, this latter technique is not considered ideal as it is difficult to guarantee asepsis, and can be dangerous to the surgeon. An alternative would be to castrate in a recumbent position, but then one of the main advantages of the used laparoscopic technique is lost. Therefore a study was started to castrate descended testicles in the standing horse using a laparoscopic technique. The mesorchium in- cluding the testicular artery and vein are ligated intraabdominally and the testicles are left in place. From earlier studies (Ensink and Klein 1996, Wilson et al 1996), performed in horses in recumbency under general anesthesia, it is known that the testicle will atrophy.

In this paper the surgical procedure, the post-operative period and the histological consequences for the testicle are described.

\section{Materials and methods}

Six Welsh pony stallions, 2 years of age, each with 2 normally descended testicles, were used. The ponies were held of feed for 2 days. The ponies were restrained in 
stocks and sedated with detomidine (Domosedan $® 0.1$ $\mathrm{mg} / 100 \mathrm{~kg}$ BWT) together with butorphanol (Nubaine ${ }^{\circledR}$ $0.1 \mathrm{mg} / \mathrm{kg}$ BWT). Local infiltration anesthesia (Lidocaine hydrochloride) was provided at the sites of the laparoscope and instrument portals in the paralumbar region. Preparations for aseptic surgery were carried out using routine technique.

The portal for the laparoscope (diameter $10 \mathrm{~mm}$, length 57 $\mathrm{cm}$, straight forward $\mathrm{O}$ angle, Storz $($ ) was located just dorsal to the internal oblique abdominal muscle and $2 \mathrm{~cm}$ cau$\mathrm{dal}$ to the last rib. After introduction of the laparoscope the abdomen was distended using a carbon dioxide $\left(\mathrm{CO}_{2}\right)$-insufflator (Storz ${ }^{\circledR}$, flowrate $7-8 \mathrm{~L} / \mathrm{min}$ ) to a maximal intra-abdominal pressure of $6 \mathrm{~mm} \mathrm{Hg}$. The second trocar (guarded disposable with a reducer) was inserted under laparoscopic supervision, approximately $4 \mathrm{~cm}$ caudal and $8-10 \mathrm{~cm}$ distal to the laparoscopic portal, directed caudalventrally. This instrument portal was used for the introduction of the ligature. The laparoscope was directed caudally and the vaginal ring was visualised. The mesorchium was perforated using a grasping forceps just proximal to the vaginal ring and lateral to the bloodvessels (Fig.1) and a ligature (polyglactin 910, Vicryl USP2, Ethicon) was inserted through this perforation. The ligature was picked up with the forceps on the mediocaudal side of the spermatic cord and retracted extracorporally (Fig. 2). A modified Roeders knot was tied extracorporally and the slipknot was advanced with a pushrod, while pulling the long tail of the ligature, and tightened. The suture was cut adjacent to the knot. The mesorchium, including the ductus deferens and spermatic cord, was ligated twice and the testicle remained in place. The same procedure was performed on the other side. The insertion portals were closed in two layers (polyglactin USP 2-0).

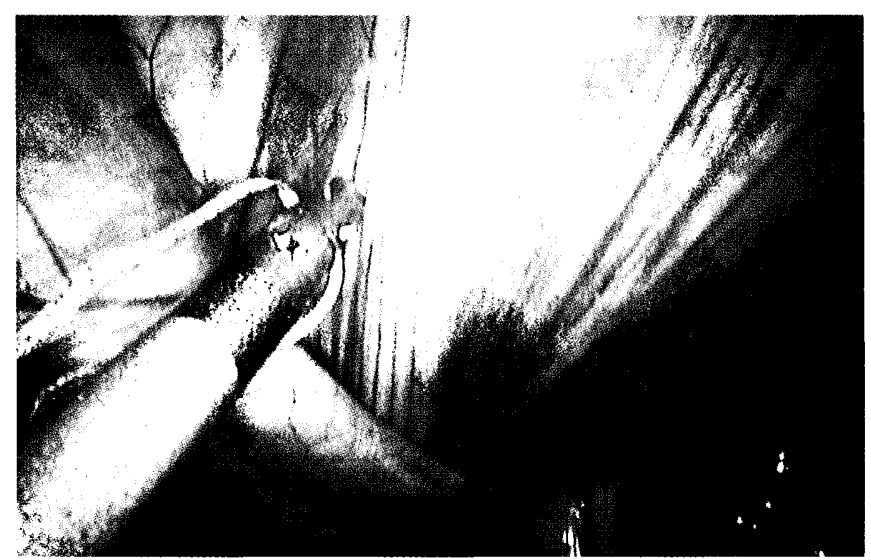

Fig 1: Laparoscopic view of the vaginal ring and the mesorchium on the right side of the pony. The forceps with the ligature points to the mesorchium at the place where it will be perforated.

Laparoskopische Sicht auf Vaginalring und Mesorchium rechtsseitig. Die Klemme mit der Ligatur deutet auf die Stelle des Mesorchium, die perforiert werden wird.

Immediately preoperatively, 7 days later and just before euthanasia plasma testosteron levels were determined (radioimmunoassay as described by Verjans et al 1973, Diele- man et al. 1983). Plasma for WBC and serum fibrinogen determination was collected on day 0 , day 1 , day 4 and day 7 postoperatively. In two ponies peritoneal fluid was obtained 24 hours post operatively.

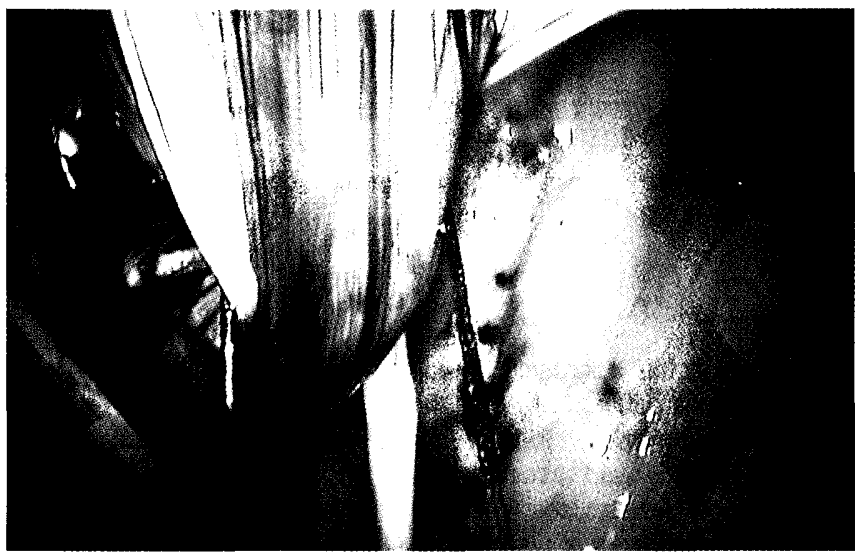

Fig 2: Laparoscopic view of the mesorchium, including the testicular artery and vein, with the ligature in place, but not yet tightened.

Laparoskopische Sicht auf das Mesorchium samt Arterie und Vene, mit der vorgelegten Ligatur

The ponies were kept at pasture and examined clinically on a daily basis for the first week and then weekly for 5 months. The testicles were palpated to determine consistency and measured with sliding callipers on day 0 , day 7 , day 28 , and just before euthanasia.

One pony was euthanised 1 week postoperatively, the other 5 at 5-6 months postoperatively. The testicles were examined histologically for the presence of spermatogenesis and the abdomen examined for adhesions or any other complications due to surgery.

Futhermore, the same laparoscopic surgery technique was performed on 9 unilateral inguinal cryptorchids, one bilateral inguinal cryptorchid, 17 unilateral abdominal cryptorchids (of which 5 were castrated unilaterally), 2 bilateral abdominal cryptorchids and 12 "normal" stallions. (14 Warmblood horses, 12 Friesian, 12 Ponys, 1 Trotter, 1 Quarterhorse und 1 Arabian ; 2-12 year; average 3,3 years). The only difference, was that before surgical manipulation the mesorchium was anaesthetised by injection of $4 \mathrm{ml} 2 \%$ Lidocain through a $36-\mathrm{mm}$ aspirating Needle (Storz) to reduce the reaction during the tigthening of the ligature.

\section{Results}

Laparoscopy was performed without complications in all ponies. Visualisation of the vaginal ring was excellent. Perforation of the mesorchium did not result in a painful reaction from the pony. Some reaction was seen when the mesorchium, including the testicular artery and vein, was ligated. Postoperative recovery was rapid. Some oedema of the scrotal skin was noted in 2 ponies between day 2 and day 5 . The testicles were not painful on palpation, nor did the ponies show any lameness or manifest any abdominal discomfort. Woundhealing was by first intention. 
During the first postoperative week the size (length and width) of the testicle increased in all ponies at an average of $3 \mathrm{~mm}$ (Table 1). Then the testicle decreased in size and 5 months postoperatively they were not palpable anymore. Immediately postoperatively the testicles became firm on palpation and remained so as long as they were palpable. The mean testosteron level before surgery was 322 (range 150-560) $\mathrm{pg} / \mathrm{ml}$ (Table 2). By day 7 the testosteron level had dropped to below the detection level of the assay $(<25$ $\mathrm{pg} / \mathrm{ml}$ ) in all ponies and was the same level just before euthanasia.

Tab 1: Average size in $\mathrm{mm}$ of both testicles during the time span of the experiment. n. p.= not palpable.

Durchschnittliche Größe in $\mathrm{mm}$ beider Hoden während der Dauer des Experiments. N. p. = nicht palpierbar.

\begin{tabular}{|l|c|c|c|c|c|c|}
\hline pony & $\begin{array}{c}\text { Day } \\
\mathbf{0}\end{array}$ & $\begin{array}{c}\text { week } \\
\mathbf{1}\end{array}$ & $\begin{array}{c}\text { week } \\
\mathbf{4}\end{array}$ & $\begin{array}{c}\text { week } \\
\mathbf{8}\end{array}$ & $\begin{array}{c}\text { week } \\
\mathbf{1 2}\end{array}$ & $\begin{array}{c}\text { week } \\
\mathbf{2 0}\end{array}$ \\
\hline 1 & 62 & 65 & 50 & 25 & n.p. & n.p. \\
\hline 2 & 61 & 65 & 40 & 25 & 20 & n.p. \\
\hline 3 & 64 & 67 & 55 & 48 & 28 & n.p. \\
\hline 4 & 63 & 66 & 50 & 45 & 30 & n.p. \\
\hline 5 & 63 & 65 & 55 & 41 & 28 & n.p. \\
\hline Mean & 63 & $\mathbf{6 6}$ & $\mathbf{5 0}$ & $\mathbf{3 7}$ & - & n.p. \\
\hline
\end{tabular}

Tab 2: Average testosteron level in $\mathrm{pg} / \mathrm{ml}$ at day 0 and day 7 .

Durchschnittlicher Testosteron-Blutspiegel in $\mathrm{pg} / \mathrm{ml}$ a Tag 0 und Tag 7

\begin{tabular}{|l|l|l|}
\hline Pony & $\begin{array}{l}\text { Testosteron } \\
\mathrm{pg} / \mathrm{ml} \text { day 0 }\end{array}$ & $\begin{array}{l}\text { Testosteron } \\
\mathrm{pg} / \mathrm{ml} \text { day } 7\end{array}$ \\
\hline 1 & 150 & $<25$ \\
\hline 2 & 560 & $<25$ \\
\hline 3 & 420 & $<25$ \\
\hline 4 & 290 & $<25$ \\
\hline 5 & 190 & $<25$ \\
\hline mean & 322 & $<25$ \\
\hline
\end{tabular}

The mean WBC count of all ponies was $9.2 \mathrm{G} / \mathrm{L}$ on D0, $11.4 \mathrm{G} / \mathrm{L}$ on D1, $10.3 \mathrm{G} / \mathrm{L}$ on D4, $8.9 \mathrm{G} / \mathrm{L}$ on D14 (table 3). The mean differential cell counts were $27 \%$ neutrophils on D0, $52 \%$ on D1, $36 \%$ on D4 and $41 \%$ on D14. These values indicate that there was no acute inflammation or peritonitis present at any time. The abdominal fluid analyses revealed no changes pointing towards a peritonitis.

At necropsy no adhesions at the portal sites or the inguinal rings were noted in any of the ponies.

Gross examination of the testicles of the pony euthanised 1 week postoperatively revealed congestion of the plexus pampiniformis. The cut surface was swollen and reddish. Histology showed coagulation necrosis of testicular tissue and no functional tissue could be found.

The size of the testicles of the remaining 5 ponies was $2 \times 2$ $x 1 \mathrm{~cm}$ on average. In 2 cases one of the testicles was attached to the vaginal tunic; more proximally no adhesions were found on the spermatic cord. The remaining cases showed no adhesions of the testicles to the vaginal tunic. The cut surface of the testicles was yellowish green at the periphery with a dull reddish brown colour in the centre (Fig. 3). Histology of the testicles showed fibrosis and in one pony (both testicles) coagulation necrosis. in 3 ponies locally intact seminiferous tubules and Leydig cells were found.

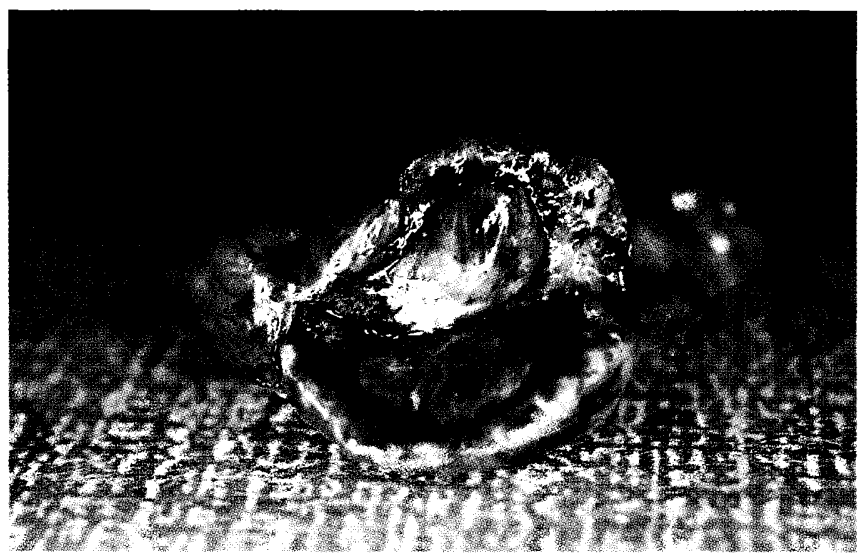

Fig 3: Macroscopic view of the incised necrotic testicle.

Makroskopischer Längsschnitt durch einen nekrotischen Hoden.

All patients underwent the surgery quietly. Postoperatively, in most horses mild oedema in the scrotum was noticed between the second and fifth day, which gradually resolved. On the second day, in 5 horses a slight increase in temperature (until $39.5 \mathrm{C}$ ) occurred which lasted 2 days.

Tab 3: Blood parameters on Day 0, 1, 4 and 14 after the surgical intervention.

Blutwerte an den Tagen 0, 1, 4 und 14 nach dem chirurgischen Eingriff.

\begin{tabular}{|l|c|c|c|c|c|c|c|c|c|c|c|}
\hline & \multicolumn{4}{|c|}{ Day 0 } & \multicolumn{2}{c|}{ Day 1 } & \multicolumn{3}{c|}{ Day 4 } & \multicolumn{3}{c|}{ Day 14 } \\
\hline & wbc g/l & pmn's \% & fibr g/l & wbc g/l & pmn's \% & wbc g/l & pmn's \% & fibr g/l & wbc g/l & pmn's \% & fibr g/l \\
\hline 1 & 6.8 & 21 & 2.4 & 8.8 & 25 & 7.3 & 37 & 2.4 & 7.1 & 24 & 1.9 \\
\hline 2 & 8.9 & 41 & 2.5 & 12.2 & 76 & 11.9 & 35 & 2.6 & 7.3 & 56 & 2.2 \\
\hline 3 & 12.6 & 17 & 2.4 & 14.4 & 37 & 13.7 & 17 & 2.5 & 7.7 & 34 & 2.6 \\
\hline 4 & 8.6 & 29 & 1.7 & 9.1 & 55 & 8.3 & 53 & 3.0 & 8.3 & 49 & 2.8 \\
\hline 5 & 9.2 & 27 & 2.1 & 12.3 & 69 & 10.3 & 64 & 2.2 & 9.6 & 42 & 2.4 \\
\hline Mean & $\mathbf{9 . 2}$ & $\mathbf{2 7}$ & $\mathbf{2 . 2}$ & $\mathbf{1 1 . 4}$ & $\mathbf{5 2}$ & $\mathbf{1 0 . 3}$ & $\mathbf{3 6}$ & $\mathbf{2 . 5}$ & $\mathbf{8 . 9}$ & $\mathbf{4 1}$ & $\mathbf{2 . 4}$ \\
\hline
\end{tabular}

$w b c=$ white blood cells

$\mathrm{g} / \mathrm{l}=$ grams $/$ liter

pmn's = polymorphonuclear neutrophits

fibr = fibrinogen 
The mean WBC count (Day 0, 1 und 7) and fibrogen determination of the blood (Day 0 and 1 ) revealed no elevations. Also, leaving the abdominal testicle inside the abdomen resulted in no clinical problems In 2 horses the testosteron level did not drop to below the detection level of the assay. These horses were castrated the conventional way under general anesthesia.

The tunica vaginalis was adhered for $3-4 \mathrm{~cm}^{2}$ to the testicle. The cut surface of these testicles (both the normal descended testicle) showed necrosis for $3 / 4$ of the testicle.

\section{Discussion}

Castration of descended testicles by double ligation through laparoscopic intervention, without removal of the testicle, can be performed successfully and may turn out to be an important step forward in the use of the laparoscopic technique in equine medicine. It is technically simple to perform and very useful for the castration of the normally descended testicles in case of unilateral abdominal cryptorchism. This testicle will atrophy in the scrotum. General anaesthesia and positioning in dorsal recumbency are avoided by operating on the standing horse. The reported incidence of post-anesthetic myopathy ranges from 0.75 to $6.4 \%$ of equine anesthetic cases (Klein 1978, McCarville and Blais 1986, Richey et al 1990, Peek 1993; Rijkenhuizen and van Dijk 1998). By using a surgical technique in a standing horse, a lot of post-operative complications are prevented and therefore a real difference to the other laparoscopic castration methods described in literature. Other possible indications for laparoscopic castration in the standing horse include all forms of cryptorchism and the castration of horses with normally descended testicles.

For the castration two portals are needed on each side of the horse: one for the laparoscope and one instrument portal. When only two instruments are used to manipulate, there is no need for an assistant surgeon.

The procedure was performed while the ponies were sedated and restrained in a stock to minimize the risk to the animals, the personnel and the equipment. Withholding feed for 2 days allows for a good view in the abdomen and reduces the risk of perforating the viscera during insertion of the trocar. To further reduce this risk, the administration of hyosin butylbromide (Buscopan $\AA$ ) might be considered. The spleen is situated on the left and with the chosen sedation, which prevents an increase in the spleen size, the risk of puncture of the spleen is reduced.

The intra-abdominal pressure of $6 \mathrm{mmHg}$ did not give rise to any signs of abdominal discomfort. The ponies and patients tolerated the surgical intervention without needing additional restraint. The only moment some discomfort was shown, was the moment when the first ligature was tightened in the ponies. However this was limited to some uneasiness and an occasional kick. In the patients the mesorchium was anaesthetised which reduces this reaction, but if the volume of analgesics is large or if it is injected exactly at the place of the ligature, the volume of the tissue that has to be ligated increases. Tightening of the ligature is then harder to perform and the risk of insufficient ligation increases. This might have been a cause of the failure in the 2 patients.

When the testicle is left in situ no additional disruption of the abdominal wall for the exteriorisation of the testicle is necessary. Additionally, this procedure reduces the risk of excessive post operative swelling or infection and there is no risk of post operative herniation with evisceration. By avoiding sharp division of the spermatic cord another advantage towards the method described by Wilson et al 1996 ) is reached with the castration method in this article. No bleeding surface is present inside the abdomen, thus creating a lower risk for the formation of adhesions. Whether revascularisation may occur is a subject for discussion, but in these ponies no signs of revascularisation were found.

The initial increase in size of the testicle is the result of congestion caused by the ligation of the vessels in the mesorchium. This congestion resolves within one week. No adverse reactions were noticed because of the fact that the testicle was left in place. Only small, hardly palpable, remnants are present at 5 months post operatively. These remnants will present no problems with ownership changes.

In this study the testicular artery and vein are neither dissected nor transected as described by Wilson et al (1996); the mesorchium, including the artery and vein, is only ligated, thus reducing the risk of intra-abdominal bleeding.

Failure of the castration technique occurred in 2 patients, probably because of an ineffective ligation of the mesorchium and ductus deferens, as the result of a loose knot or ligation of insufficient tissue, meaning not including all the vessels. Revascularisation is very unlikely to occur within 7 days postoperatively. Also it is important to include the ductus deferens in the ligature, because the artery beside the ductus is able to vascularise the testicle sufficiently for producing testosteron.

Disadvantages of this technique are the size of the area that has to be clipped, the cost of the equipment and the manpower needed to connect the tubes and cables and the care of the equipment including the surgical instruments, the postoperative measurement of the testosteron level and the need for training of the surgeon.

In conclusion, the surgical technique described in this report is safe and represents an efficient method of castrating descended testicles in the standing patient. Advantages include reduced tissue trauma, no risk because of general anaesthesia, a quicker return to normal work and reduced hospitalization time.

\section{Literature}

Davis E.W. (1997): Laparoscopic cryptorchidectomy in standing horses. Vet. Surgery 26, 326-331

Dieleman S.J., Th. A. N. Kruip, P. Fonteyne, W. H. R. de Jong and G. C. van der Weyden (1983): Changes in oestradiol, progesterone and testosterone concentrations in follicular fluid and in the micrimorphology of preovulatory bovine follicles relative to the peak of luteinizing hormone. J Endocrinol 71, 31-42 
Fischer A. T. and A. M. Vachon (1992): Laparoscopic cryptorchidectomy in horses. J Am Vet Med Assoc 200, 1705-1708

Ensink J. M. and W. R. Klein (1996): Castration of horses and ponies by ligation of the spermatic cord. Proc. Scientific Meeting ECVS 5, 142

Klein L. (1978): A review of 50 cases of post-operative myopathy in the horse - intrinsic and management factors affecting risk. Proc. Am. Assoc. Equine Pract 24, 89-94

MCCarville E. and D. Blais (1986) Myopathy after general anesthesia in the horse: literature review and a retrospective study of thirteen clinical cases. Med Vet Quebec 16, 17-20

Peek M. L. (1993): A case of post-anesthetic myopathy. Equine Vet Educ 5, 183-186

Richey M. T., M. S. Holland, C. J. McGrath, N. H. Dodman, D. B. Marshall, M.H. Court, W.M. Norman and D. C. Seeler (1990): Equine
Post-anesthetic Lameness. A retrospective study. Vet Surg, 19, 392-397

Verjans H. L., B. A. Cooke, F. H. de Jong, C. M. M. de Jong and H. J. van der Molen (1973): Evaluation of radioimmunoassay for testosterone estimation. J Steroid Biochem 4, 665-676

Wilson D. G., D. A. Hendrickson, A. J. Cooley and E. Degrave-Madigan (1996): Laparoscopic methods for castration of equids. J Am Vet Med Assoc 209, 112-114

Prof. Astrid B. M.Rijkenhuizen

Faculty of Veterinary Medicine

Equine Science, Surgery

Yalelaan 12

NL 3584 CM Utrecht

\section{Leistungsdiagnostik der tiefen Atemwege beim Sportpferd}

\section{Fortbildungsveranstaltung}

der Arbeitsgruppe Pferd in Zusammenhang mit der

Akademie für tierärztliche Fortbildung

unterstützt von CORTEX Biophysik

und ESSEX Tierarznei

\section{6. - 17. Oktober 1999, Hannover}

Tagung am 16. Oktober 1999 im Holiday Inn Crown Plaza, Hannover-Flughafen

Kurs am 17. Oktober 1999 in der Klinik für Pferde, Tierärztliche Hochschule Hannover

Wie wird die Leistungsdiagnostik der Atemwege beim Sportpferd in Guelph (Kanada), Hannover und Utrecht durchgeführt? Ekkehard Deegen (Hannover), Roel Nieuwstadt (Utrecht), Henry Staempfli (Guelph)

- Klinische Untersuchung

- Endoskopie (in Ruhe und während des Laufens)

- Tracheobronchialspülung und Lavage

- Blutgase

- Lungenfunktionsanalyse

1. Block: Wenn das Pferd gesund ist

2. Block: Wenn das Pferd nicht ausreichend leistet

3. Block: Wenn das Pferd krank ist

Impfung gegen Atemwegserkrankungen: Was spricht scheinbar dagegen?

Peter Hinsberger, München

Was bringt die Sauerstoffmessung beim laufenden Pferd im Feld?

Arno Lindner, Bonn

- Blutgase

- Lungenfunktionsanalyse

Anmeldung und Information:

Frau Stück, ATF, Bundestierärztekammer, Oxfordstraße 10, 53111 Bonn, Tel.: $10228 \mid 72546$ 40, Fax: 1022817254666 mit Verrechnungsscheck

Teilnehmergebühren: für Tagung am Samstag den 16.10.99 bis 10. Oktober 1999200 DM, (ATF- und FFP-Mitglieder 180 DM), danach und an der Tageskasse 250 DM (ATF- und FFP-Mitglieder 230 DM DM); inkl. 16\% MwSt., Kaffeepausen, Mittagsbuffet und Getränke für Kurs (Teilnehmerzahl auf 20 beschränkt) am 17.10. 99 DM 500 (ATF- und FFP-Mitglieder 450 DM); inkl. 16\% MwSt., Kaffeepause und Lunchpaket

ATF Anerkennung 10 Stunden 